\title{
Evaluation of multisite performance of SWAT model in the Gomti River Basin, India
}

\author{
Biswajit Das $^{1} \cdot$ Sanjay Jain ${ }^{1} \cdot$ Surjeet Singh ${ }^{1} \cdot$ Praveen Thakur $^{2}$
}

Received: 8 January 2019 / Accepted: 24 June 2019 / Published online: 6 July 2019

(c) The Author(s) 2019

\begin{abstract}
The basin was calibrated through monthly discharge for the period (2002-2008) including 2 years as warm-up (2000-2001), after that model was validated on 5 years of hydrometeorological datasets (2009-2013) at two gauge sites located at Neemsar (upstream gauge) and Lucknow (downstream gauge). It is found that the most sensitive parameter for moisture condition II (CN2) was initial curve number. The $p$-factor and $r$-factor were obtained in calibration period at Neemsar 0.73 and 0.58 while at Lucknow values are 0.79 and 0.51 , whereas in validation period values are $0.61,0.45$ and $1.22,0.75$, respectively. Three statistical parameters have been used to evaluate the SWAT model performance such as Coefficient of Determination $\left(R^{2}\right)$, Nash-Sutcliff efficiency (NSE), percent bias (PBIAS). The NSE and $R^{2}$ values were observed as $0.85,0.84$ and $0.87,0.86$, respectively, in the time of calibration period and values is $0.76,0.76$ and $0.79,0.83$, respectively, in the time of validation period at two above said gauging stations. The PBIAS values during calibration and validation period are $-13.3,-14.7$ and $-4.0,-15.7$, respectively, at the same gauge site which indicates good model performance result.
\end{abstract}

Keywords SWAT model $\cdot$ Gomti river basin $\cdot$ Sensitivity analysis $\cdot$ SUFI-2 algorithm

\section{Introduction}

Watershed modeling is a combination of hydrometeorological data and geospatial techniques. It is a successful technique for understanding the planning of management of water resources in a sustainable way within a basin. Distributed hydrological simulation model with embedded Geographical Information System (GIS) is effective toll for the hydrologists as well as planners of water resources. It is a simple model combination of hydrometeorological data (Zhang et al. 2012). The capability of a hydrological model must be predicting the result with sufficient accuracy for long-term hydrological scenario analysis. Wheater (2007) suggested the "simulations of catchment yield under seasonal and annual climate variability results in low and high stream flow and is often a challenge." In India, where the variability of climate is high and the availability of

Biswajit Das

biswajitdasrs@gmail.com

1 National Institute of Hydrology, Roorkee, Uttarakhand 247667, India

2 IIRS, Dehradun, Uttarakhand 248001, India water is limited (Greg 2006). According to CWC (2005) in India, availability of per capita annual water resources has decreased from $5176 \mathrm{~m}^{3}$ in 1951 to $1588 \mathrm{~m}^{3}$ in 2015 , respectively, and it will further decrease to $1434 \mathrm{~m}^{3}$ in 2025 .

According to USDA, Agricultural Research Service Soil and Water Assessment Tool (SWAT) model is developed to delineate watershed and river basin analysis study (Arnold et al. 1998). The SWAT model is filled with hydrometeorological datasets, to simulate the flow of rivers, the sediment and the water quality. SWAT model proved to be an effective evidence to evaluate the land management practices in floodplain and agricultural chemicals and water resources (Shi et al. 2011). In various countries, SWAT model has been extensively used as a river discharge estimator (Spruill et al. 2000). Shi et al. (2011) conducted a research on "Evaluating the SWAT Model for Hydrological Modeling in the Xixian Watershed and a Comparison with the XAJ Model" to understand the model performance on water resources in China. Saha et al. (2013) carried out "Streamflow modeling in a fluctuant climate using SWAT in Yass River catchment," to predict the flow and compared with the observed data in southeastern Australia. Shivhare et al. (2014) examined the performance of "Simulation of Surface Runoff for Upper Tapi Sub-basin Area (Burhanpur Watershed) Using SWAT"; 
from 1992 to 1997. Sisay et al. (2017) examined the "Hydrological modelling of ungauged urban watershed using SWAT model" in Vadodara city of Gujarat. Singh et al. (2013) conducted a study on "Hydrological stream flow modelling on Tungabhadra catchment: parameterization and uncertainty analysis using SWAT CUP." Gyamfi et al. (2016) conducted the study on "application of SWAT model to the Olifants Basin: calibration, validation and uncertainty analysis." Kumar et al. (2017) predicted the "SWAT model calibration and uncertainty analysis for streamflow prediction of the Tons river basin, India, using sequential uncertainty fitting (SUFI-2) algorithm" in India. Jain et al. (2010) suggested that the watershed management is a technique which is based on water quality and quantity. Variation in management of river basin is based on time and from place to place. Improvement in watershed management somewhere in terms of the good watering method and sustain the drinking water quality. Another intention may be to minimize the high surface runoff for regulating the decay of soil and sediment. However, rainfall-runoff modeling is essential for better management of sustainable water resource (Jain et al. 2010).

Physical and chemical properties of water are the important parameters to study hydrology and its interaction with the surroundings. Increase in demand of fresh water is due to an increase in pattern of consumption and its overexploitation. In recent times, excessive wasteful use of water resources is a major problem which is relevant to properly preserving and maintaining water resources (Srinivas et al. 2016). Based on the hydrometeorological datasets for the prediction of stream flow of a river, SWAT hydrological model plays an important role. SWAT model has been selected to assess the hydrological simulation of Gomti river basin (9923.42 sq km) from Fulhar Jheel to up to GD site at Lucknow using gridded hydrometeorological datasets at two different gauging stations (Neemsar and Lucknow) which are used to model calibration and validation. Using available hydrometeorological datasets simulates the range of hydrological sensitive parameters and carried out an analysis of the relationship between the simulated models discharge and observed discharge at the gauging stations. The main purposes of this study are to assess the Evaluation of Multisite performance of SWAT Model for Hydrological Modeling in the Gomti river basin, India, with sensitivity analysis and calibration. This study contributes to the understanding on the part of planning of water resource management and soil erosion in a sustainable way.

\section{Study area}

Gomti is an important alluvial tributary of the Ganga River flowing through the Indo-Gangetic Plain. It originates in Uttar Pradesh from "Fulhar Jheel" in Madhotanda near Mainkot which is situated $30 \mathrm{~km}$ in the eastern part of the Pilibhit town (Fig. 1). In Varanasi (UP), Kaithi is the
Fig. 1 Location map of the Gomti basin

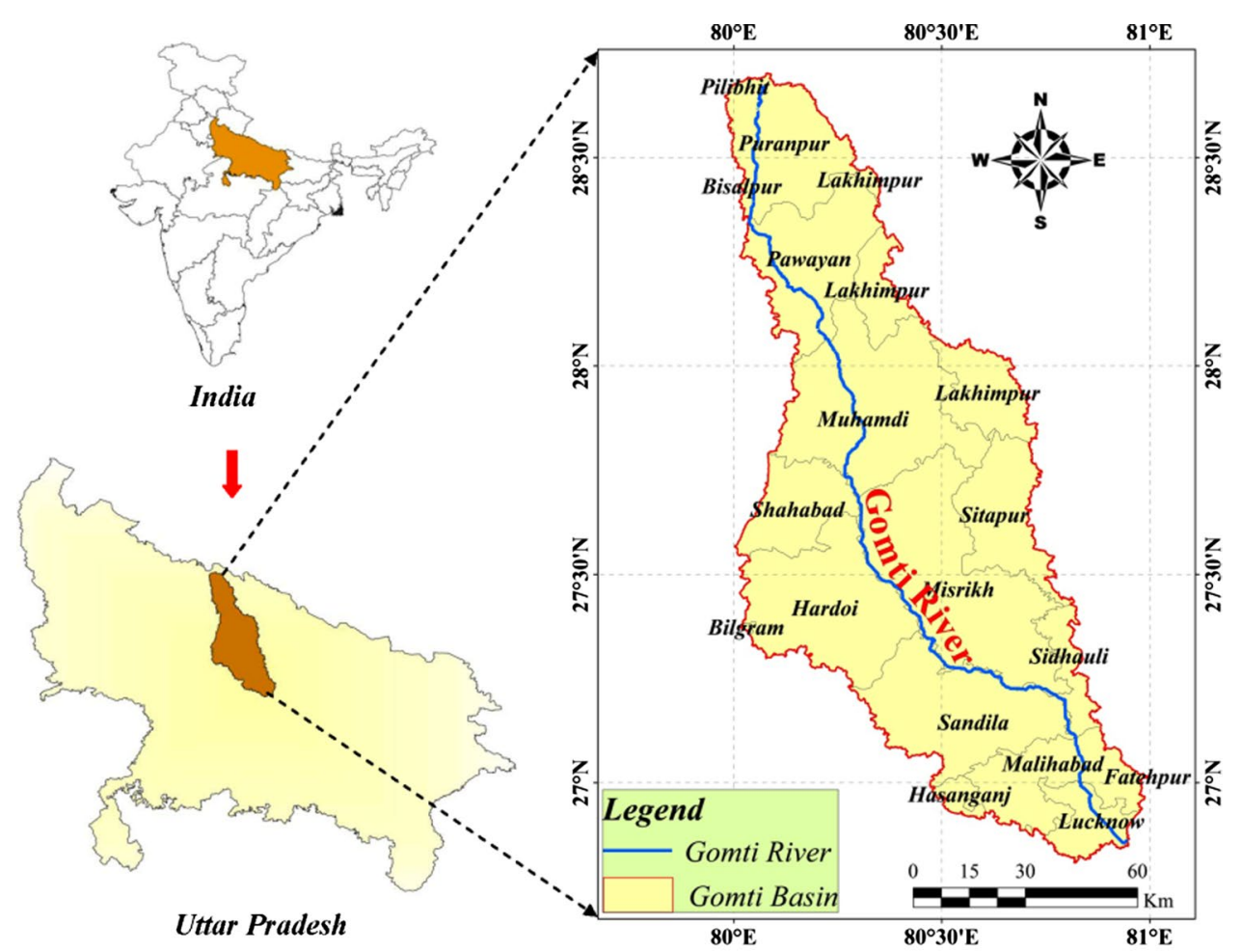

Study Area 
confluence of Gomti with the Ganga River. The study area of the Gomti river basin is $9923.42 \mathrm{sq} \mathrm{km}$ up to G \& D site at Lucknow and lies between $27^{\circ}$ North and $28^{\circ} 30^{\prime}$ North latitudes and $80^{\circ}$ East' to $81^{\circ}$ East' longitudes. The minimum and maximum elevation of the basin varies from 98 and $216 \mathrm{~m}$ above mean sea level. The annual average precipitation varies between 850 and $1100 \mathrm{~mm}$. About $70 \%$ of total annual precipitation occurs between June and September from the South-West Monsoon. The basin is influenced by a semi-arid to sub-humid tropical climate (Rai et al. 2014). The Gomti River is the primary source of water supply to the residing cities of the river and other downstream habitations.

\section{Methodology and materials}

\section{SWAT model}

Soil and Water Assessment Tool (SWAT) is a river basinscale model that is developed to measure the impact of land management practices in large, complex reservoirs. It deals with the following elements with the hydrology model: Weather, surface waterway, return flow, water source, ventilation, transmission loss, pond and reservoir storage, crop growth and irrigation, underground flow, reaching path, nutrition and pesticide loading, and water transfers. SWAT uses Hydrological Response Unit (HRU), which describes local diversity, which constitutes the land cover, soil characteristics, and land slope characteristics of unique land use.

SWAT model is based on the principle of water balance equation:

$\mathrm{SW}_{t}=\mathrm{SW}_{o}+\sum_{i=1}^{t}\left(R_{\text {day }}-Q_{\text {surf }}-E_{\mathrm{a}}-W_{\text {seep }}-Q_{\mathrm{gw}}\right)$

where $\mathrm{SW}_{t}$ is the ultimate water content in $(\mathrm{mm}), \mathrm{SW}_{o}$ is the amount of water content on the first soil of the day $i(\mathrm{~mm}), t$ is time (days), $R_{\text {day }}$ is the amount of rainfall on day $i(\mathrm{~mm})$, $Q_{\text {surf }}$ is the amount of surface runoff on specific day $i(\mathrm{~mm})$, $E_{\mathrm{a}}$ is the amount of evapotranspiration on day $i(\mathrm{~mm}), W_{\text {seep }}$ is the amount of percolated water into the vadose zone from the soil profile on day $i(\mathrm{~mm})$ and $Q_{\mathrm{gw}}$ is the amount of return flow on day $i(\mathrm{~mm})$.

\section{Input forcing data and model setup}

The SWAT model requires intensive hydrometeorological data to run the dynamics of watershed. The major hydrometeorological data include metrological data, LULC (Land use Land Cover) map and soil texture. For the study of the Gomti river basin, the following datasets are prepared: (1) A Digital Elevation Model (DEM) from SRTM (30 m resolution) has been used for basin delineation, Stream network

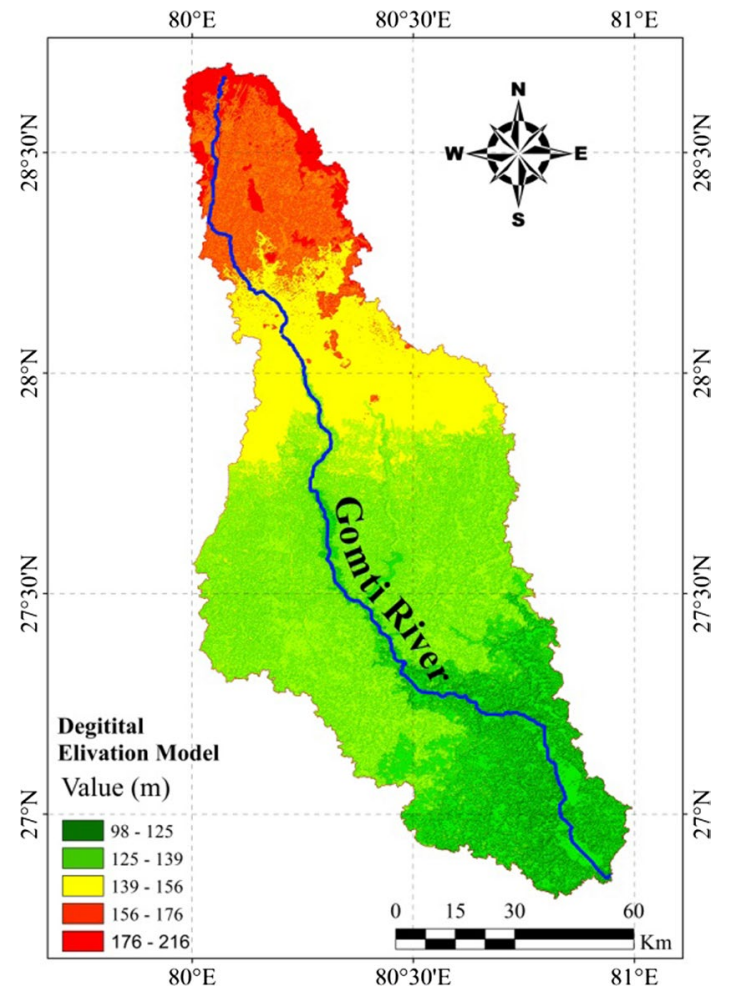

Fig. 2 Digital elevation map of the study area

and sub-basins (Fig. 2). (2) A year 2017 LULC was prepared from LANDSAT-8 (30 m resolution) and is projected to coordinate system (WGS 1984 UTM Zone 43 North). The LULC of the basin has been prepared using supervised classification technique, and it is presented in Fig. 3. The LULC has water, dense forest, sparse vegetation, builtupland, agricultural crop and fallow land. (3) A soil map (including texture) of the basin has been downloaded from the site of IIT Delhi (http://gisserver.civil.iitd.ac.in/grbmp ). Three different kinds of soil classes have identified in this basin area as shown in Fig. 4. (4) Daily gridded climate data (2000-2013) such as maximum and minimum air temperature, wind speed, solar radiation and relative humidity with a spatial resolution of $0.30^{\circ} \times 0.30^{\circ}$ have been downloaded from Global Weather Data for SWAT (https://globalweather. tamu.edu). (5) Daily gridded precipitation data (2000-2013) with a spatial resolution of $0.25^{\circ} \times 0.25^{\circ}$ have been obtained from Indian Metrological Department (http://www.imdpu ne.gov.in). (6) Measured river discharge data of two gauging stations at Neemsar and Lucknow are used to calibration and validation of the model (Fig. 5).

\section{SUFI-2 algorithm}

In SUFI-2, uncertainty in parameter accounts for all sources of uncertainties such as uncertainty in driving variables, conceptual model, parameters, and measured data (Abbaspour

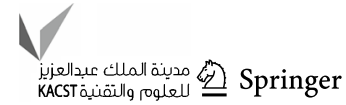




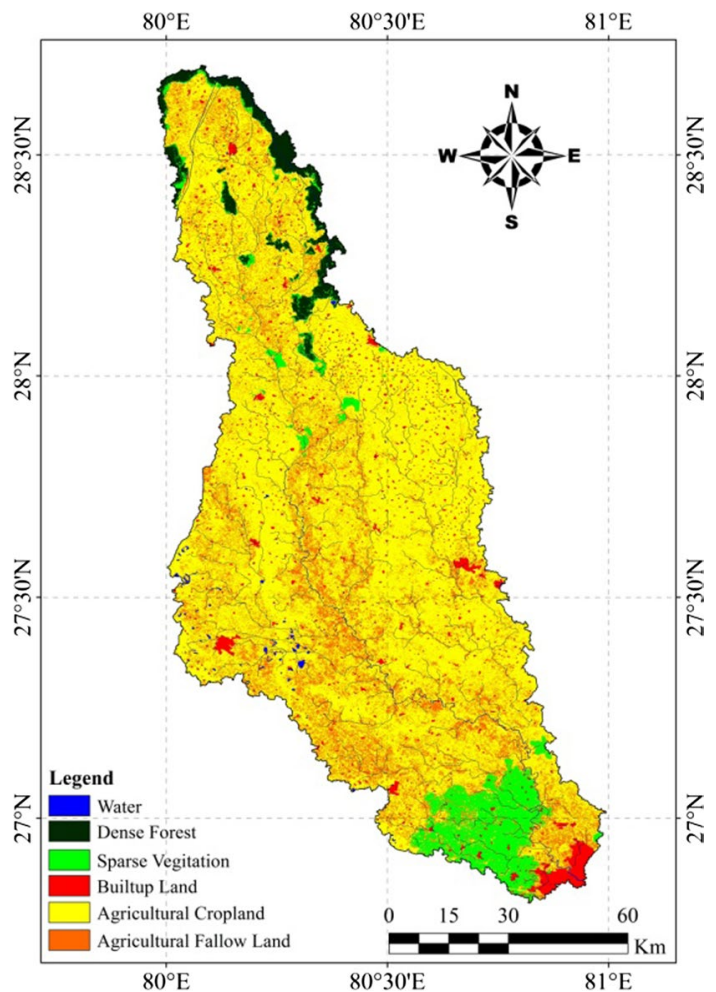

Fig. 3 LULC map of the study area

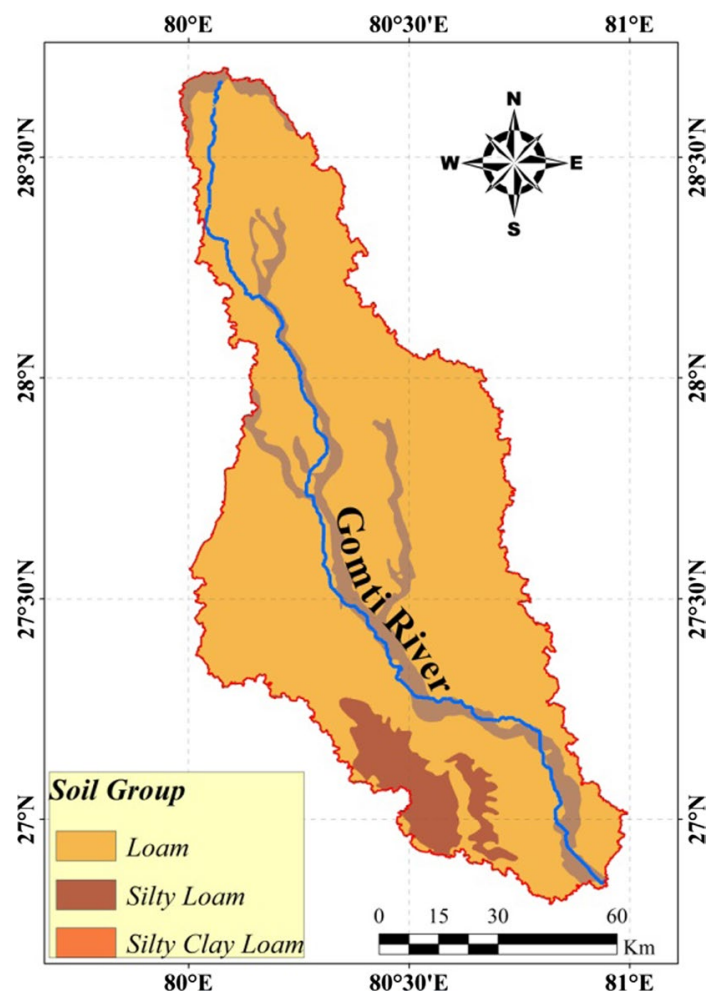

Fig. 4 Soil map the study area

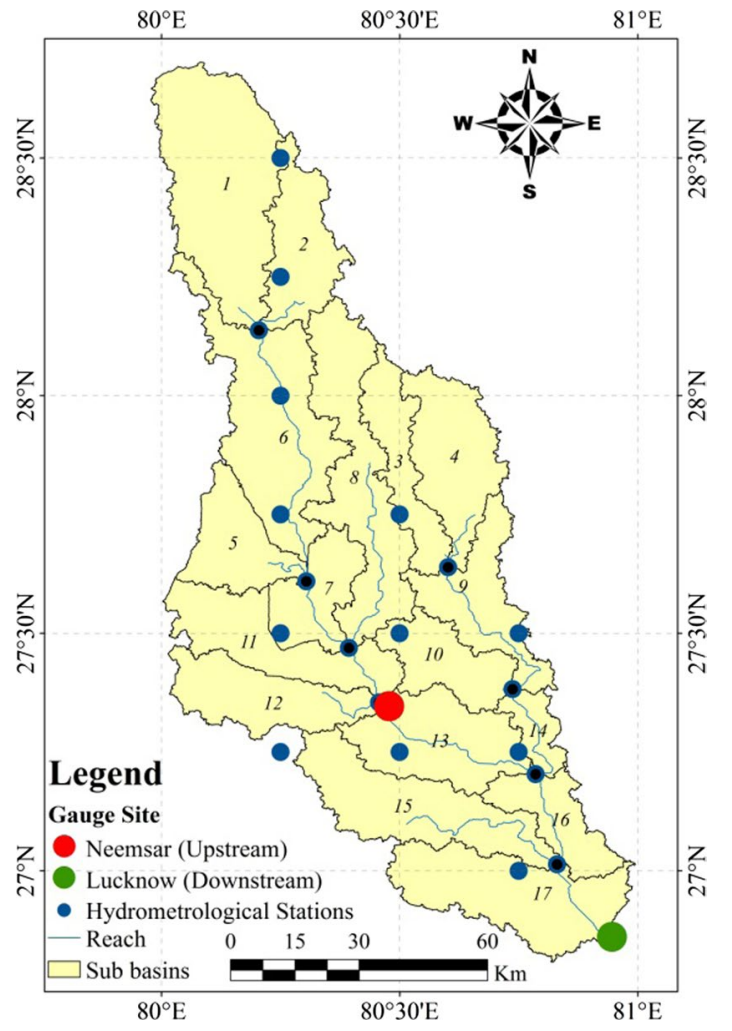

Fig. 5 Hydrometeorological stations with gauging sites

et al. 2015). The incremental distribution of an output variable obtained by the Latin Hypercube sample of 95 PPU (Percent Prediction Uncertainty) is calculated at 2.5\% and 97.5\% level (Abbaspour et al. 2007). 1 value of $p$-factor represents the highest quality, that is, $100 \%$ of the brackets surveyed and illustrate high uncertainties in low-quality outputs (Abbaspour et al. 2015; Arnold et al. 2012). The $r$-factor and $p$-factor are the potency of calibration of model and determination of uncertainty (Abbaspour et al. 2015; Arnold et al. 2012). $P$-factor value 1 represents the highest quality, that is, $100 \%$ of the brackets measured and illustrates high uncertainties in low-quality outputs (Setegn et al. 2009). $R$-factor describes the quality of calibration values and if it is close to zero, then combined with measured data (Yang et al. 2008). The lower price for the low uncertainty is considered favorable and shows 1 high uncertainty. It requires a balance between $p$-factor and $r$-factor because the larger $p$-factor can only be achieved at high-factor. When the acceptable values of both factor reach, the parameter uncertainties are in the calibrated parameter range (Abbaspour et al. 2004, 2009).

\section{Model performance indices}

To evaluate the performance of model, three statistical parameters have been used such as: Coefficient of 
Determination $\left(R^{2}\right)$ (Krause et al. 2005), Nash-Sutcliff efficiency (NSE) and percent bias (PBIAS). $R^{2}$ is calculated as:

$$
\begin{aligned}
R^{2}= & \left\{\sum_{t=1}^{T}\left(Q_{m, t}-\bar{Q}_{m}\right)\left(Q_{s, t}-\bar{Q}_{s}\right) /\left[\sum_{t=1}^{T}\left(Q_{m, t}-\bar{Q}_{m}\right)^{2}\right]^{0.5}\right. \\
& {\left.\left[\sum_{t=1}^{T}\left(Q_{s, t}-\bar{Q}_{s}\right)^{2}\right]^{0.5}\right\}^{2} }
\end{aligned}
$$

where $\bar{Q}_{m}=$ Observed variable, $\bar{Q}_{s}=$ Simulated variable. Ranges of $R^{2}$ are from 0.0 to 1.0. Higher value of $R^{2}$ indicates better model performance. The formula for calculating NSE is:

$\mathrm{NSE}=1.0-\sum_{t=1}^{T}\left(Q_{m, t}-Q_{s, t}\right)^{2} /\left[\sum_{t=1}^{T}\left(Q_{m, t}-\bar{Q}_{m}\right)^{2}\right]$

NSE indicates the statistical relationship between models simulated and observed values. Nash and Sutcliffe (1970) recommended the "values of NSE vary from $-\infty$ to $1 . "$ Higher value of NSE indicates better model performance.

PBIAS is calculated as:

PBIAS $=\left(\sum_{t=1}^{T}\left(Q_{s, t}-Q_{m, t}\right) / \sum_{t=1}^{T}\left(Q_{m, t}\right)\right) \times 100$

where $Q_{s, t}=$ Simulated variables. $Q_{m, t}=$ Observed variables, and $t=1,2, \ldots, T$. Gupta et al. (1999) recommended "PBIAS measures the average tendency of the simulated values to be larger or smaller than their observed ones. Positive PBIAS values indicate model underestimation and negative values over estimation."

\section{Results and discussion}

\section{Parameter sensitivity}

A sensitivity analysis has been implemented during calibration period using SWAT-CUP to identify sensitive parameters. To reduce parameter dimension, the sensitivity analysis plays a crucial role. It helps us reducing time during the period of model calibration. The hydrological parameter which is sensitive for model performance was calibrated until a satisfied agreement between the model simulated and observed values was acquired using sensitivity analysis method. Surface runoff is an important aspect of water resources which depends on SCS curve number (CN2), permeability of soil function, land use land cover and presence of water in soil (Parajuli et al. 2007; Wang et al. 2008). The parameters considered for the calibration including CN2, ALPHA_BF, GW_DELAY, GWQMIN, DEEPST, REVAPMN, RCHRG_DP, CANMX, SURLAG, SOL_BD, SOL_AWC, SOL_ALB and SOL_K. The range of parameters and the fitted values are given in Table 1. At both gauging stations (Neemsar and Lucknow), CN2 was the most sensitive parameter found among all the 13 parameters for the Gomti river basin at monthly time-step (Fig. 6a, b). The other parameters are found less sensitive. The simulations were carried out for two gauge sites located at Neemsar (upstream gauge) and at Lucknow (downstream gauge).

\section{Model calibration and validation}

Calibration is the coordination of the model's parameters and the uncertainty in the margins of the arbitrage, which acquires a model representation of interest processes that are pre-agreed criteria (James and Burges 1982). Thus, calibration procedure involves systematic coordination of hydrological parameters' estimate so that simulated model results more accurately match with the observed variables. Figure 7 shows the detailed methodological framework. For calibration, sensitivity analysis is usually carried out to identify the impact and rank of hydrological parameters on model output The SWAT model calibration and validation were carried out by SWAT-CUP analysis tool using the SUFI2 approach. The model calibration was performed by adopting the concept of aggregate parameter selection (Yang et al. 2008). A collective parameter, such as a $v_{-}, a_{-}$and $r_{-}$, is defined by adding a word as a predefined parameter to a predetermined parameter, relative to a full increment and initial parameter value, respectively (Yang et al. 2008; Zhang et al. 2014).

The performance of calibration of a model depends on the length of data used. Figure 7 shows a schematic of model calibration process. The temporal data series are generally separated into two sets: calibration and validation dataset. Normally, in calibration period, more number of year's data (about 60 to 70\%) is used. In the present work monthly average discharge data from January 2000 to December 2008 were used during calibration period and rests of the data from January 2009 to December 2013 were used to validate the performance of model at two different gauge sites, i.e., Neemsar and Lucknow. Data for the first 2 years (from January 2000 to December 2001) were used as "warmup" period, and it is not considered for the performance of model. To evaluate the model performance during the process of calibration, the hydrological parameters were adjusted systematically to acquire the good result between simulated and observed value. And in the time of validation, the basin variables were simulated with the calibrated parameters without any change and simulated discharge was compared with the observed discharge. 
Table 1 Calibrated values of sensitive hydrologic parameters at two gauging stations in the Gomti river basin
Fig. 6 a Sensitivity of hydrological parameters at Neemsar. b Sensitivity of hydrological parameters at Lucknow

\begin{tabular}{|c|c|c|c|c|c|}
\hline \multirow[t]{2}{*}{ Parameters and description } & \multirow[t]{2}{*}{ Min value } & \multirow[t]{2}{*}{ Max value } & \multicolumn{2}{|c|}{ Fitted_value } & \multirow[t]{2}{*}{ Process } \\
\hline & & & Neemsar & Lucknow & \\
\hline $\begin{array}{l}\mathrm{CN} 2 \\
\text { (curve number II) }\end{array}$ & -25.94 & 8.04 & -25.22 & -24.34 & Run-off \\
\hline $\begin{array}{l}\text { ALPHA_BF } \\
\text { (base flow alpha factor) }\end{array}$ & 0.14 & 0.15 & 0.14 & 0.14 & Groundwater \\
\hline $\begin{array}{l}\text { GW_DELAY } \\
\text { (groundwater delay) }\end{array}$ & 63.56 & 64.10 & 63.60 & 63.91 & Groundwater \\
\hline $\begin{array}{l}\text { GWQMN } \\
\text { (threshold depth occur in } \mathrm{mm} \text { of } \mathrm{H}_{2} \mathrm{O} \text { ) }\end{array}$ & 802.46 & 1747.96 & 983.05 & 1151.35 & Groundwater \\
\hline $\begin{array}{l}\text { DEEPST } \\
\text { (initial depth deep aquifer in } \mathrm{mm} \text { of } \mathrm{H}_{2} \mathrm{O} \text { ) }\end{array}$ & $27,640.80$ & $28,923.20$ & $27,657.47$ & $28,886.01$ & Groundwater \\
\hline $\begin{array}{l}\text { REVAPMN } \\
\text { (threshold depth to occur in } \mathrm{mm} \text { of } \mathrm{H}_{2} \mathrm{O} \text { ) }\end{array}$ & 352.22 & 384.08 & 359.52 & 362.89 & Groundwater \\
\hline $\begin{array}{l}\text { RCHRG_DP } \\
\text { (deep aquifer fraction) }\end{array}$ & 0.57 & 0.77 & 0.72 & 0.66 & Groundwater \\
\hline $\begin{array}{l}\text { CANMX } \\
\text { (maximum storage in mm) }\end{array}$ & 1.07 & 1.16 & 1.11 & 1.09 & Runoff \\
\hline $\begin{array}{l}\text { SURLAG } \\
\text { (surface runoff lag coefficient (days) }\end{array}$ & -4.25 & 1.62 & -1.48 & -4.02 & Runoff \\
\hline $\begin{array}{l}\text { SOL_BD } \\
\text { (moist density }\left(\mathrm{Mg} / \mathrm{m}^{3}\right)\end{array}$ & 1.13 & 1.13 & 1.13 & 1.13 & Soil \\
\hline $\begin{array}{l}\text { SOL_AWC } \\
\text { (available soil layer (mm soil) }\end{array}$ & -13.33 & 12.23 & 0.34 & 0.50 & Soil \\
\hline $\begin{array}{l}\text { SOL_ALB } \\
\text { (moist soil albedo) }\end{array}$ & -20.53 & 9.83 & -18.86 & -8.36 & Soil \\
\hline $\begin{array}{l}\text { SOL_K } \\
\text { (saturated soil layer in } \mathrm{mm} / \mathrm{h} \text { ) }\end{array}$ & -4.33 & 37.03 & 30.37 & 30.95 & Soil \\
\hline
\end{tabular}

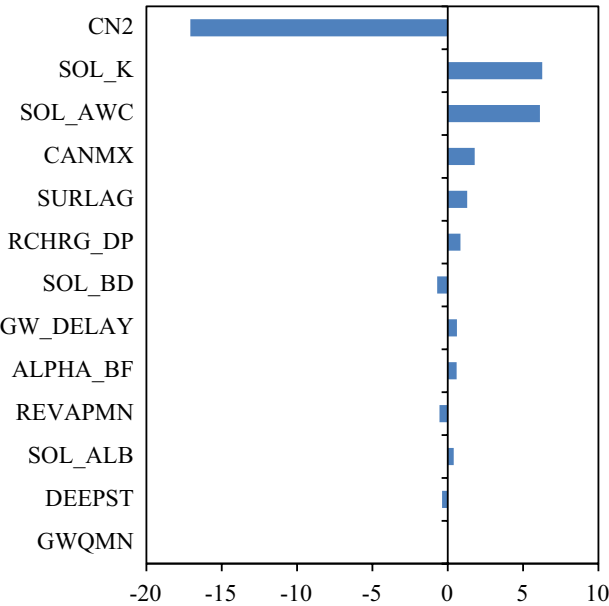

(a)

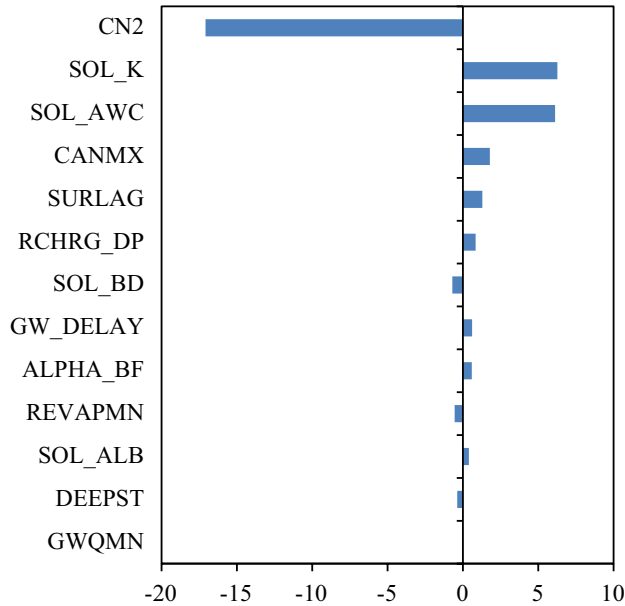

(b)
At Neemsar GD site $r$-factor and $p$-factor were obtained as 0.73 and 0.58 , respectively, while at Lucknow the $r$ and $p$-factor were obtained as 0.79 and 0.51 , respectively, during calibration period and validation period the value were obtained as $0.61,0.45$ and $1.22,0.75$, respectively. Figures 8 and 9 show monthly flow hydrographs for the observed and simulated discharge pattern. Moriasi et al. (2007) recommended "the general performance of objective functions on monthly time step calibration are satisfactory as if $\mathrm{NSE}>0.50$ and $\mathrm{RSR} \leq 0.70$, and if PBIAS $\pm 25 \%$ for streamflow, PBIAS $\pm 55 \%$ for sediment, and PBIAS $\pm 70 \%$ for $N$ and $P$." Nash and Sutcliffe (1970) described as "NSE value greater than 0.75 (good simulation) and for satisfactory (greater than 0.36)." Van Liew and Garbrecht (2003) 
Fig. 7 Detailed methodological framework

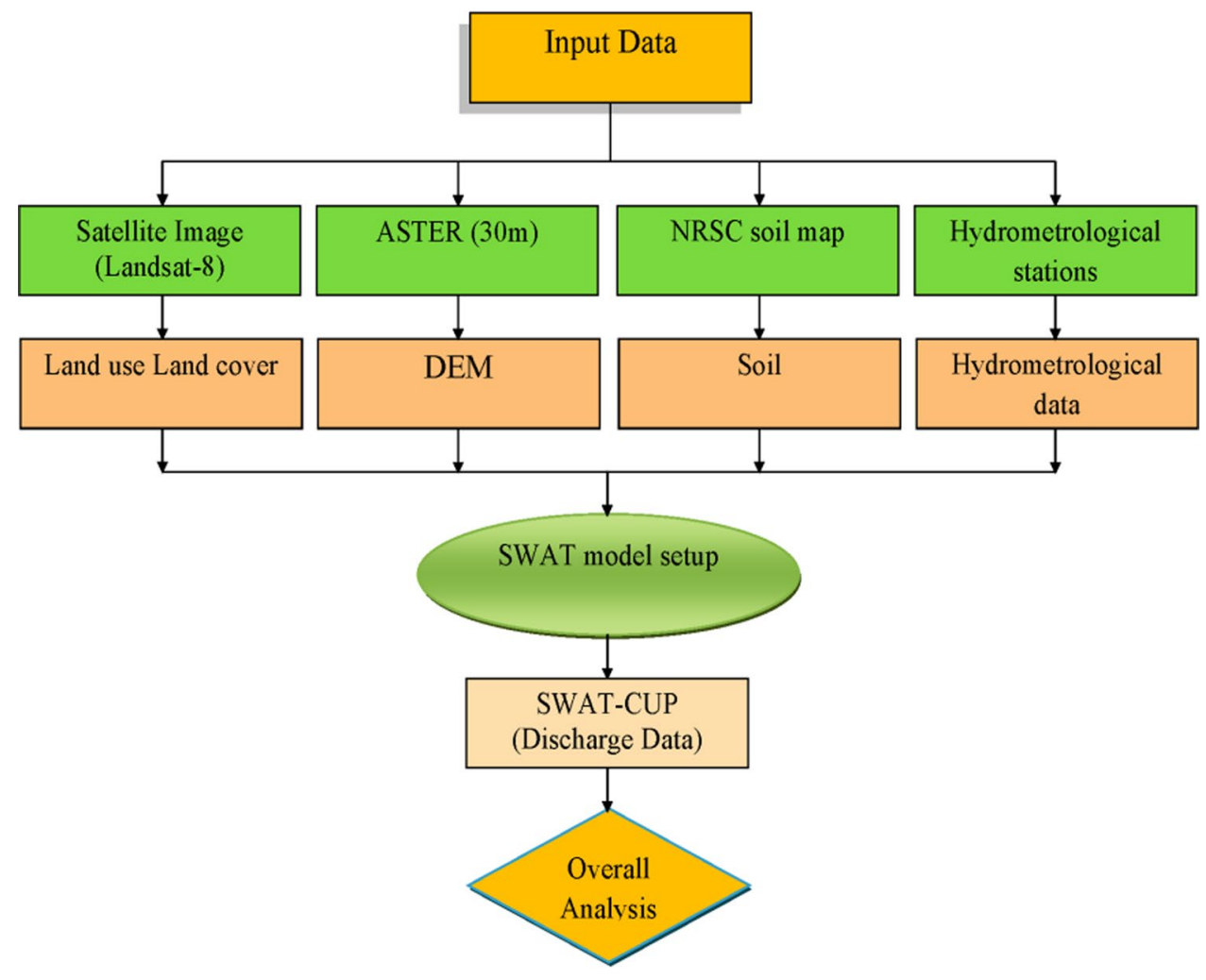

Fig. 8 Observed and simulated monthly flows at Neemsar

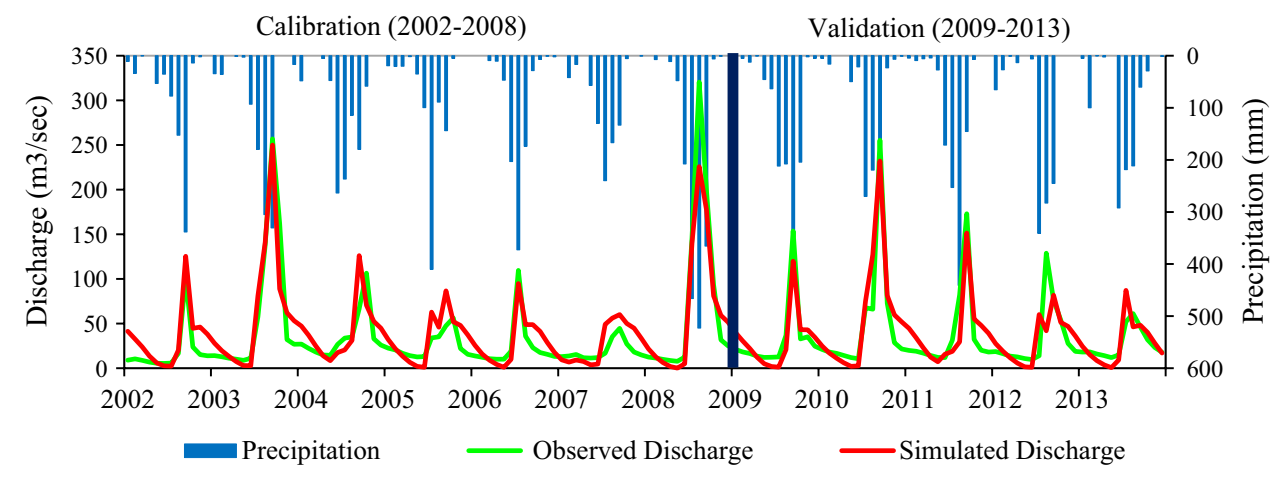

Fig. 9 Observed and simulated monthly flows at Lucknow

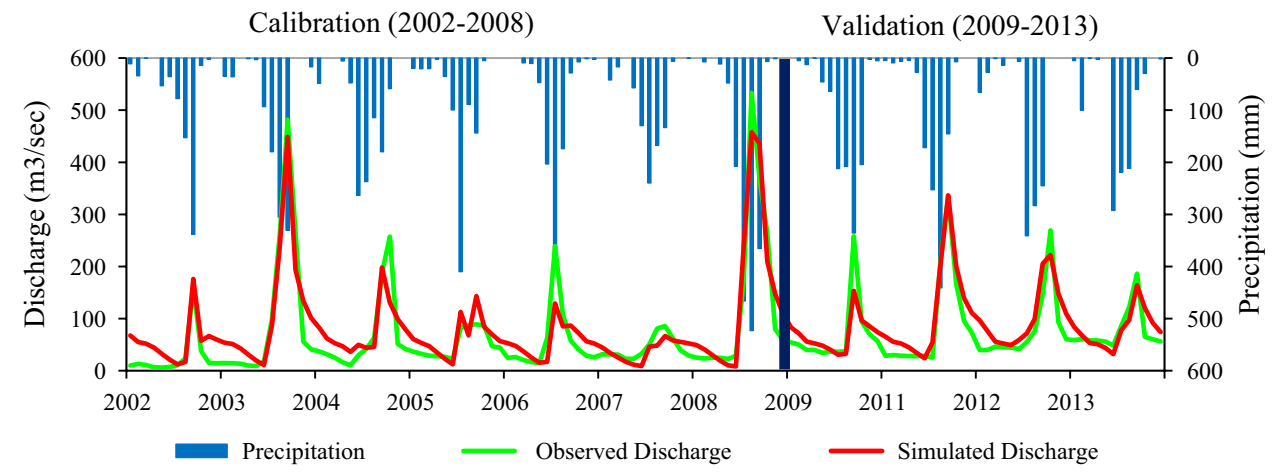

recommended that "the value of $R^{2}$ should be greater than 0.5." At upstream gauging site (Neemsar) and downstream site (Lucknow), the NSE and $R^{2}$ values were observed as
$0.85,0.84$ and $0.87,0.86$, respectively, during calibration period and the during validation period were $0.76,0.76$ and $0.79,0.83$, respectively (Figs. 8,9 ). The PBIAS value during 
Fig. 10 a Correlation between calibrated results at Neemsar during calibration. b Correlation between validated result at Neemsar during validation

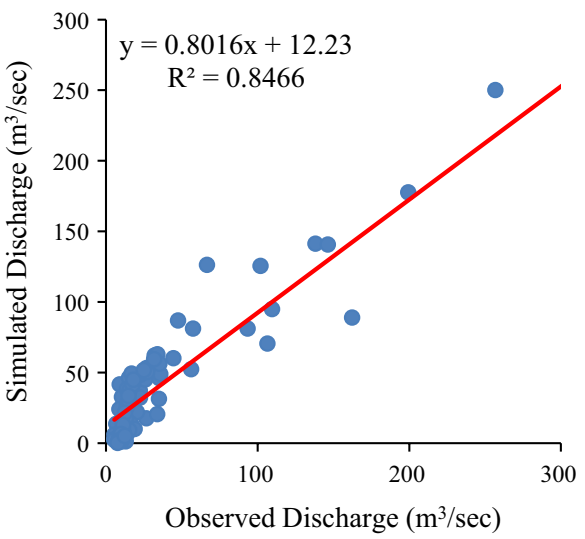

(a)

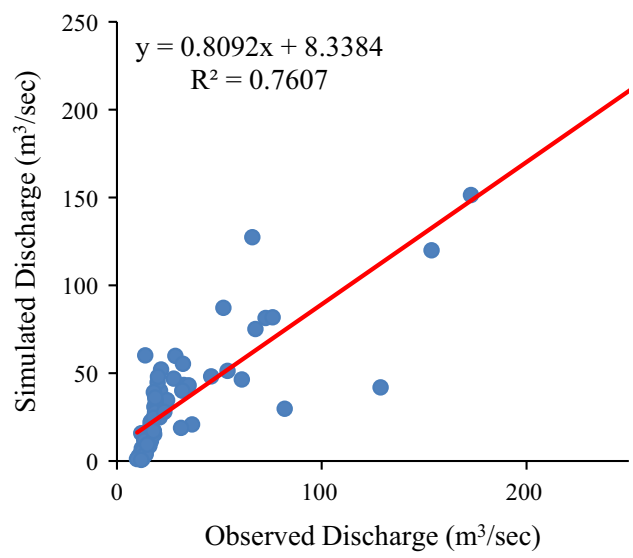

(b)
Fig. 11 a Correlation between calibrated results at Lucknow during calibration. b Correlation between validated result at Lucknow during validation

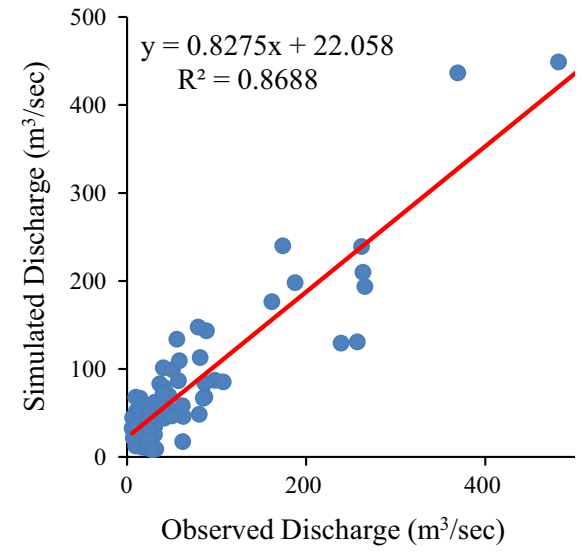

(a)

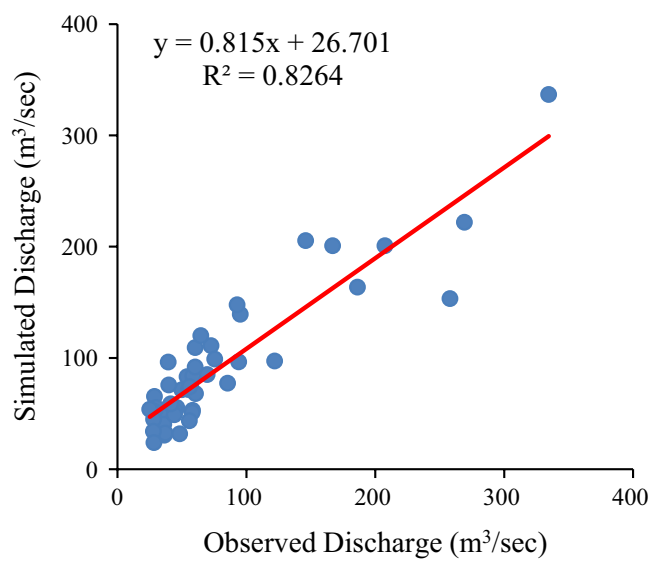

(b) calibration and validation period is $-13.3,-14.7$ and -4.0 , -15.7 , respectively, at the same gauge site. All these criteria indicate good model performance and a classy agreement between the observed and simulated values. The scatter plot (Figs. 10a, b, 11a, b) shows the familiarity between models simulated and observed variables with good correlation during calibration and validation period at Neemsar and Lucknow.

\section{Source of uncertainty}

The SUFI2 (Sequential Uncertainty Fitting) algorithm developed by Abbaspour et al. $(2004,2007)$ was used in the present work. Abbaspour et al. $(2004,2007)$ recommended that "the Uncertainty is an interface for calibration, validation, uncertainty, and sensitivity analysis of SWAT model and it converges with relatively smaller number of iterations and provides possibility of restarting an unfinished iteration and split iteration into several runs."

Singh et al. (2007) suggested that there are basically five uncertainties sources in the hydrologic modeling such as "natural uncertainties associated with random temporal and spatial fluctuations in natural processes, model structure uncertainty reflecting the inability of the model to precisely represent the system, uncertainty in the parameters-reflecting non-uniqueness of model parameters and inability to determine their right values, uncertainties in the observed data arise from the measurement inaccuracy and inadequacy of gauging networks, and computational uncertainties."

Uncertainties are important in hydrological model because these are survey at fixed points and represent large areas. The variation of error of uncertainties in mountainous region is maximum due to the reason of complexity and variation in topography. Due to sparse gauging networks, climate data of the station nearest to the centroid of the subbasin are normally taken to represent the conditions of that sub-basin. Direct accounting of metrological inputs such as precipitation or distribution in temperature error is quite difficult because the information's are frequently not available from many stations. 


\section{Conclusions}

To understand the status of water resources as well as hydrological process in the Gomti river basin, SWAT model was applied. Calibration of validation was performed at two gauging sites using SUFI-2 algorithm in SWAT-CUP on monthly basis. The hydrometeorological dataset on a daily time basis at Neemsar and Lucknow gauge sites was used as input data to run the model. Compared the SWAT simulated discharge with the measured discharge data at both gauging stations. 13 years (2000-2013) datasets have been arranged for model setup, first 2 years (2000-2001) data was kept as warm-up time for the model. Out of these 13 years, 8 years dataset (2002-2008) was used for calibration period and 5 years (2009-2013) for validation period of model, respectively. For calibration of model, uncertainty analysis SWAT-CUP has been used and Global Sensitivity Analysis for identified the most sensitive and ranges of various hydrological parameters for the basin. SWAT-CUP has been used for model calibration and. Out of thirteen parameters (CN2, ALPHA_BF, GW_DELAY, GWQMN, DEEPST, REVAPMN, RCHRG_DP, CANMX, SURLAG, SOL_BD, SOL_AWC, SOL_ALB and SOL_K). It is found that the most sensitive parameter for moisture condition II (CN2) was initial curve number. Model performance has been done using three statistical parameters such as Nash-Sutcliff efficiency (NSE), Coefficient of Determination $\left(R^{2}\right)$, percent bias (PBIAS). The NSE and $R^{2}$ values were observed as $0.85,0.84$ and $0.87,0.86$, respectively, during calibration period and the values during the period of validation are $0.76,0.76$ and $0.79,0.83$, respectively, at two gauging stations. The PBIAS values during calibration and validation period are $-13.3,-14.7$ and $-4.0,-15.7$, respectively, at the same gauging stations which indicate good model performance result. The model indicated very good agreement between simulated and observed flow. Therefore, it can be concluded that the performance of model has strong predictive capability for the Gomti river basin.

\section{Compliance with ethical standards}

Conflict of interest The authors declare that they have no conflicts of interest.

Open Access This article is distributed under the terms of the Creative Commons Attribution 4.0 International License (http://creativeco mmons.org/licenses/by/4.0/), which permits unrestricted use, distribution, and reproduction in any medium, provided you give appropriate credit to the original author(s) and the source, provide a link to the Creative Commons license, and indicate if changes were made.

\section{References}

Abbaspour KC, Johnson A, van Genuchten MTh (2004) Estimating uncertain flow and transport parameters using a sequential uncertainty fitting procedure. Vadose Zone J 3(4):1340-1352

Abbaspour KC, Vejdani M, Haghighat S, Yang J (2007) SWAT-CUP calibration and uncertainty programs for SWAT. In: MODSIM 2007 international congress on modelling and simulation, modelling and simulation society of Australia and New Zealand, pp 1596-1602

Abbaspour KC, Faramarzi M, Ghasemi SS, Yang H (2009) Assessing the impact of climate change on water resources in Iran. Water Resour Res 45:W10434. https://doi.org/10.1029/2008WR007615

Abbaspour KC, Rouholahnejad E, Vaghefi S, Srinivasan R, Yang H, Kløve B (2015) A continental-scale hydrology and water quality model for Europe: calibration and uncertainty of a high-resolution large-scale SWAT model. J Hydrol 524(1):733-752. https://doi. org/10.1016/j.jhydrol.2015.03.027

Arnold JG, Srinivasan R, Muttiah RS, Williams JR (1998) large area hydrologic modeling and assessment part I: model development. JAWRA 34(1):73-89. https://doi.org/10.1111/j.1752-1688.1998. tb05961.x

Arnold JG, Moriasi DN, Gassman PW, Abbaspour KC, White MJ, Srinivasan R, Santhi C, Harmel RD, van Griensven A, Van Liew MW, Kannan N, Jha MK (2012) SWAT: model use, calibration, and validation. Trans ASABE 55(4):1494-1508

Central Water Commission (2005) Water data complete book 2005. http://www.cwc.nic.in/main/downloads/Water_Data_Compl ete_Book_2005

Greg M (2006) Living in a variable climate: Australia's variable climate. Department of sustainability, environment. Water, population and communities. http://www.environment.gov.au/soe/2006/ publications/integrative/climate/variable-climate.html. Accessed 9 April 2013

Gupta HV, Sorooshian S, Yapo PO (1999) Status of automatic calibration for hydrologic models: comparison with multilevel expert calibration. J Hydrol Eng 4(2):135-143

Gyamfi C, Ndambuki JM, Salim RW (2016) Application of SWAT model to the Olifants Basin: calibration, validation and uncertainty analysis. J Water Resour Prot 8:397-410

Jain SK, Tyagi J, Singh V (2010) Simulation of runoff and sediment yield for a Himalayan watershed using SWAT model. J Water Resour Prot 2(03):267-281

James LD, Burges SJ (1982) Selection, calibration, and testing of hydrologic models. In: Haan CT, Johnson HP, Brakensiek DL (eds) Hydrologic modeling of small watersheds. ASAE Monograph, St. Joseph, pp 437-472

Krause P, Boyle DP, Bäse F (2005) Comparison of different efficiency criteria for hydrological model assessment. Adv Geosci 5:89-97. https://doi.org/10.5194/adgeo-5-89-2005

Kumar N, Singh SK, Srivastava PK, Narsimlu B (2017) SWAT model calibration and uncertainty analysis for streamflow prediction of the Tons river basin, India, using sequential uncertainty fitting (SUFI-2) algorithm. Model Earth Syst Environ. https://doi. org/10.1007/s40808-017-0306-Z

Moriasi D, Arnold J, Van Liew M, Bingner R, Harmel R, Veith T (2007) Model evaluation guidelines for systematic quantification of accuracy in watershed simulations. Trans ASABE 50(3):885900. https://doi.org/10.13031/2013.23153

Nash JE, Sutcliffe JC (1970) River flow forecasting through conceptual models. Part I-a discussion of principles. J Hydrol 10:282-290

Parajuli PB, Mankin KR, Barnes PL (2007) New methods in modeling source specific bacteria scale using SWAT. ASABE publication no. 701P0207. ASABE, St. Joseph, MI, USA

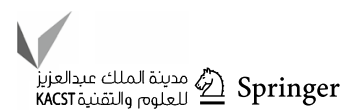


Rai SK, Kumar S, Rai AK, Palsaniya DR (2014) Climate change, variability and rainfall probability for crop planning in few districts of Central India. Atmos Clim Sci 4:394-403

Saha PP, Zeleke K, Hafeez M (2013) Streamflow modeling in a fluctuant climate using SWAT: Yass River catchment in south eastern Australia. Environ Earth Sci. https://doi.org/10.1007/s1266 5-013-2926-6

Setegn SG, Srinivasan R, Dargahi B (2009) Hydrological modelling in the Lake Tana basin, Ethiopia, using SWAT model. Open Hydrol J 2:49-62

Shi P, Chen C, Srinivasan R, Zhang X, Cai T, Fang X, Li Q (2011) Evaluating the SWAT model for hydrological modelling in the Xixian watershed and a comparison with the XAJ model. Water Resour Manag 25:2595-2612. https://doi.org/10.1007/s1126 9-011-9828-8

Shivhare V, Goel MK, Singh CK (2014) Simulation of surface runoff for upper Tapi sub catchment area (Burhanpur watershed) using swat. Int Arch Photogramm Remote Sens Spatial Inf Sci 40(8):391

Singh VP, Jain SK, Tyagi A (2007) Risk and reliability analysis: a handbook for civil and environmental engineers. ASCE Press, Reston

Singh V, Bankar N, Salunkhe SS, Bera AK, Sharma JR (2013) Hydrological stream flow modelling on Tungabhadra catchment: parameterization and uncertainty analysis using SWAT CUP. Curr Sci 40(9):1187-1199

Sisay E, Halefom A, Khare D, Singh L, Worku T (2017) Hydrological modelling of ungauged urban watershed using SWAT model. Model Earth Syst Environ 3(2):693-702

Spruill C, Workman S, Taraba J (2000) Simulation of daily and monthly stream discharge from small watersheds using the SWAT model. Trans ASAE 43:1431-1439
Srinivas JS, Kumar TKS, Reshma T (2016) Simulation of runoff for an experimental watershed using SWAT. Int J Technol Res Appl 4:364-369

Van Liew MW, Garbrecht J (2003) Hydrologic simulation of the Little Washita River experimental watershed using SWAT. J Am Water Resour Assoc 39(2):413-426

Wang S, Kang S, Zhang L, Li F (2008) Modeling hydrological response to different land use and climate change scenarios in the Zamu River basin of northwest China. Hydrol Proc 22:2502-2510

Wheater HS (2007) Modelling hydrological processes in arid and semi-arid areas: an introduction to the workshop. In: Wheater HS, Sorooshian S, Sharma KD (eds) Hydrological modelling in arid and semi-arid areas. Cambridge University Press, Cambridge

Yang J, Abbaspour KC, Reichert P, Yang H (2008) Comparing uncertainty analysis techniques for a SWAT application to Chaohe basin in China. J Hydrol 358(1-2):1-23

Zhang X, Yao J, Zhang X (2012) GIS-based physical process modelling: a spatial-temporal framework in hydrological models. In: Paper presented at the GIScience 2012, seventh international conferences on geographic information sciences, Columbus, $\mathrm{OH}$, 18-21 Sept 2012

Zhang P, Liu R, Bao Y, Wang J, Yu W, Shen Z (2014) Uncertainty of SWAT model at different DEM resolutions in a large mountainous watershed. Water Res 53:132-144

Publisher's Note Springer Nature remains neutral with regard to jurisdictional claims in published maps and institutional affiliations. 